Journal of the Scholarship of Teaching and Learning, Vol. 21, No. 1, April 2021, pp. 131-151.

doi: 10.14434/josotl.v21i1.30353

\title{
Undergraduate Research at a Teaching-Oriented College: Seniors' Perspectives and Approaches to Consider
}

\author{
Robin Herlands Cresiski \\ University of Maryland, Baltimore County \\ rcresisk@umbc.edu \\ Qingmin Shi \\ University of Nevada, Las Vegas \\ Sandip Thanki \\ Nevada State College \\ Lori Navarrete \\ Nevada State College
}

\begin{abstract}
This study examines the relationship of undergraduate research (UGR) participation on senior students' reported engagement, perceived gains, satisfaction with their educational experience and retention, and graduation status compared to peers that have not participated in UGR. Data were drawn from 1,472 senior students at a comprehensive, teaching-oriented public college, and collected from administration of the National Survey of Student Engagement (NSSE) from 2015 to 2019, along with institutional data. This examination uniquely investigates outcomes of UGR participation besides persistence and graduation (which are already well documented) and leverages the lens of senior students in particular. In addition, this study contributes to the literature on UGR at teaching-oriented colleges, which has been sparse most likely because there are many more opportunities for UGR at research institutions. In line with several conceptual frameworks of student engagement, data analysis revealed that relative to their peers who have not participated in UGR, UGR-participating students have higher levels of engagement, perceived gains, and overall satisfaction. UGR-participating students also continued enrollment and/ or graduated at a higher rate after reaching their senior status compared to non-participating peers. The implications for teaching-oriented colleges, as well as suggestions for how these institutions can enhance their undergraduate research programming, are discussed.
\end{abstract}

Keywords: undergraduate research, senior, National Survey of Student Engagement (NSSE), engagement, perceived gains, satisfaction

\section{Introduction}

Participation in undergraduate research (UGR, hereafter) has been well documented to have an impact on student success. Rightfully designated a high impact practice (Kuh, 2008), working on novel research with a faculty member positively impacts student retention and graduation and increases a student's self-identification as a scholar/scientist, which may be critical in persistence into graduatelevel study and future career choice (Eagan et al., 2013; Lopatto, 2010; Seymour et al., 2004). These outcomes are particularly notable in racial minority and first-generation populations (Carpi et al., 2017; Hurtado et al., 2010; Jones et al., 2010; Kuh, 2008; Lopatto, 2010; O’Donnell et al., 2015), which remain significantly underrepresented in the academy. Because of the reproducible data demonstrating the impact of UGR participation, institutions should expand opportunities for undergraduate research. This is easier at some institutions than others, however. 
UGR normally operates in an apprentice model: a student spends a summer or semester working significant hours under a faculty member, postdoc, or senior graduate student and often earns a stipend to do so (Lopatto, in 2010, coins this "the epitome of the undergraduate research experience"). This apprentice model is standard at research universities but is expensive in both financial and human resources since stipends are required for both mentor and mentee, and mentors typically take on just a few undergraduate mentees at a time. It is also not easily replicated at teaching colleges where faculty frequently do not have the laboratory space, support to seek grant funding for staff/equipment to conduct research, or workload accommodations that would facilitate apprenticebased research (Hu et al., 2007; Marwick, 2012). In addition, there are questions of accessibility with the apprentice model. While there has not been extensive research about why some students do not participate in research, some research indicates that lack of time and the low pay for conducting research contribute to the decision (Stout, 2018). Therefore, accessing apprentice opportunities outside of dedicated for-credit class time is limited for first-generation and low-income students that frequently work significant hours while in college (Falcon, 2015; RTI International, 2019). This was confirmed in the national Survey of Undergraduate Research Experiences (SURE), where nearly twothirds of students participating in research reported difficulty balancing time between research (in the apprentice model) with coursework and other activities (Lopatto, 2010). Despite this, little research has been done examining low-income student participation in UGR or the impacts of UGR for this population.

Teaching colleges (which represent a significant portion of the higher education market as community colleges, small liberal arts colleges, and undergraduate-focused regional comprehensive universities) have had to innovate alternative models for providing research opportunities (Wei \& Woodin, 2011). Research partnerships with community organizations (e.g., research internships for credit) and course-based undergraduate research experiences (CUREs) are two such mechanisms. CUREs can take place in science labs conducting novel research, statistics classrooms (for example, a class can act as consultants for community organizations), as history projects (archiving materials at a local historical site), or education courses centered around teacher-as-researcher projects (students study the efficacy of reading interventions), etc. CUREs have the advantage of engaging an entire class in research as opposed to a select few apprentices (Auchincloss et al., 2014; Bangera \& Brownell, 2014), and yield similar positive results in building science identity, research skills, and intention to pursue graduate education/careers in research (Auchincloss et al., 2014; Harrison et al., 2011; Jordan et al., 2014; Shaffer et al., 2010). Students participating in class-based research also have higher skill gains than summer researchers for science writing, research ethics, and understanding primary literature (Lopatto, 2010).

Alternative forms of giving students access to research are especially important in that they are achievable at all kinds of teaching institutions, including community colleges where it is estimated that half of all college-going students get their start (Center, 2017). Community colleges have innovated a wide breadth of research opportunities for undergraduates (Cejda \& Hensel, 2009; Marwick, 2012), with some emphasizing the scientific process (Brandt \& Hayes, 2012), focusing on applied research in a technical area, or investigating topics/problems of local relevance (Cejda \& Hensel, 2009). Importantly, the SURE data indicate that students engaging in alternative research experiences like these (compared to traditional apprentice programs) are just as likely to go to graduate school and go to graduate school at higher rates than peers who did not complete any UGR (Hathaway et al., 2002).

Despite the positive outcomes, there remains limited research on the outcomes of students engaging in UGR at teaching-focused institutions. Prior to this study, it has not been shown whether non-apprentice model UGR at teaching-focused institutions has similar impacts to student engagement, perceived gains, satisfaction or persistence/graduation, nor how these impacts manifest

Journal of the Scholarship of Teaching and Learning, Vol. 21, No. 1, April 2021. josotl.indiana.edu 
in populations most underrepresented in the academy. In this study, we analyzed 2015-2019 National Survey of Student Engagement (NSSE) data from senior students at a public comprehensive institution that emphasizes teaching. Senior students are a relatively untapped source of feedback that can help campus communities learn about the meaningfulness of research opportunities and the impact such opportunities have on their success (Gardner \& Veer, 1998). Surveys of senior students are important because research can occur at any level of the undergraduate experience, including during the senior year (a senior capstone, thesis, internship, project, or lab experience). We sought to examine whether there were differences in seniors' level of engagement, perceived gains, and overall satisfaction for those who did and did not participate in UGR. Further, we also wanted to examine the extent to which participation in UGR impacted persistence or graduation status after reaching senior status. This examination will help us understand the impact of research in this distinct setting and provoke greater discussion of how UGR can be implemented and leveraged at teaching-focused colleges.

\section{Methods}

\section{Study Context}

The study is situated in a comprehensive public teaching-oriented college (referred to as "the Institution" hereafter). The Institution has had a steadily growing baccalaureate population, reaching over 5,000 students in fall 2019. As a highly diverse, open-access campus, the Institution received designation from the Department of Education as a Title III \& Title IV Minority Serving Institution (MSI) in 2013. In 2015, the Institution achieved its designation as a Hispanic Serving Institution (HSI). In fall 2019, $75 \%$ of the enrolled students were female, $63 \%$ were from ethnic and racial minority backgrounds, and over 47\% were first-generation college students. The campus had a large portion $(38 \%)$ of low-income, Pell recipient students. To address the needs of such a diverse student population and all students, the Institution offers a wide range of student support initiatives, programs, and inclusive practices to assist and support students (especially traditionally underserved racial and ethnic minority, first-generation, and low-income students) and enhance the students' educational experiences. Studies like this will shed light on the benefits of participation in UGR on student engagement, perceived gains, and satisfaction, especially for traditionally underrepresented college students in teaching-oriented colleges.

\section{Data Sources and Participants}

Senior data from the Institution's 2015-2019 NSSE administrations, as well as institutional data, were used for this study. NSSE data were retrieved from NSSE through the designated institutional interface (NSSE staff administer its core survey in spring to first-year and senior-year students through a specific online survey link directly sent to eligible students and later provide each participating institution access to their data). One of the authors connected the NSSE data to the institutional data warehouse through student ID's and transferred the de-identified data to another author to conduct statistical analysis. The dataset allowed researchers to explore targeted variables related to student experiences with UGR, engagement, perceived gains, overall satisfaction, and other student success metrics.

Potential participants in this study were 1,673 senior-year students who responded to the NSSE core survey from 2015 through 2019. Of these respondents, 1,472 completed questions related to UGR and were included in the data analysis of this study. The majority of participants were female (80\%), racial and ethnic minority (47\%), first-generation (65\%), and had received Pell support (53\%).

Journal of the Scholarship of Teaching and Learning, Vol. 21, No. 1, April 2021. josotl.indiana.edu 
The demographics of these NSSE seniors in this study is similar to the campus senior population of fall 2014 to fall 2018 in terms of gender ( $76 \%$ females), race and ethnicity (55\% ethnic minority), firstgeneration status (64\%), and receipt of a Pell grant ever in their time at the Institution (55\%). Although the senior sample of this study is relatively representative of the campus senior population, caution should be practiced in interpreting and generalizing the findings.

\section{Measurement and Variables}

The NSSE core survey was used to measure senior students' participation in UGR and engagement indicators, perceived gains, and overall satisfaction (see Appendix for example items for engagement indicators, perceived gains, and overall satisfaction in NSSE survey). After a significant revision of the NSSE core survey in 2013, the NSSE core surveys of 2015 through 2019 include the same questions related to UGR, engagement, perceived gains, and overall satisfaction. This makes the items comparable year over year.

Undergraduate Research. The UGR question in NSSE was not limited to the current school year at the time of data collection; therefore, seniors' responses included their participation for all the years since they attended the college. The question asked, "Which of the following have you done or do you plan to do before you graduate?" NSSE asked students to indicate whether they have done or were in progress of working with a faculty member on a research project with four possible responses: (a) have not decided, (b) do not plan to do, (c) plan to do, and (d) done or in progress. We re-coded "d" as " 1 ", indicating UGR participation, and "a", "b", and "cc" as "O" for no UGR participation.

Engagement Indicators. Student engagement was estimated by 10 engagement indicators constructed with 47 questions, which asked students to indicate how often they have done the related activities. The question stem asked, "During the current school year, about how often have you done the following?" and then provided a list of activities, such as "combined ideas from different courses when completing assignments." The NSSE core survey designated each question with four response options (1: never, 2: sometimes, 3: often, and 4: very often).

Perceived Gains. Perceived gains were measured by 10 questions, which asked students to indicate their gains in practical competence, personal and social development, and general education competency areas as a result of their undergraduate education. The prompt asked, "How much has your experience at this institution contributed to your knowledge, skills, and personal development in the following areas?" and then had areas such as "thinking critically and analytically" and "analyzing numerical and statistical information." Each area then had four response options (1: very little, 2: some, 3: quite a bit, and 4: very much).

Overall Satisfaction. Two NSSE items were used to measure what NSSE deems "Overall Satisfaction": "How would you evaluate your entire educational experience at this institution?" and "If you could start over again, would you go to the same institution that you are attending?" Both questions had four response options (1: poor, 2: fair, 3: good, and 4: excellent; or 1: definitely no, 2: probably no, 3: probably yes, and 4: definitely yes).

In order to facilitate comparisons over time and between groups of students, scores of engagement indicators, perceived gains, and satisfaction were first converted on a 60-point scale. Then, re-coded values for each component item were calculated and averaged as a composite score for each engagement indicator. Engagement indicators were pre-calculated by NSSE, while responses of perceived gains and satisfaction questions were re-coded with values of $0,20,40$, or 60 , for 1, 2, 3, and 4, respectively, following NSSE-recommended SPSS syntax (NSSE, n.d.). The higher scores mean more frequent engagement, more perceived gains, and high-level satisfaction.

Persistence or Graduation Status. We also collected two variables of persistence or graduation status drawn from institutional data for this study. First, we used persistence as one of the indicators

Journal of the Scholarship of Teaching and Learning, Vol. 21, No. 1, April 2021. josotl.indiana.edu 
of senior student success, measured by a student either having graduated by summer after reaching senior status and completing the NSSE survey or continuing enrollment in the next fall at the Institution. A student either having graduated from or re-enrolled in the next fall at the Institution was coded as " 1 " for "persisted". Otherwise, the student was coded as " 0 " for "not persisted". Second, we included an institutional variable of "graduated by summer after reaching senior status and completing the NSSE survey" (senior status meaning the cumulative credit hours reached 90). Since these senior participants started their undergraduate career at different years, we believe that it is a fair comparison of graduation status after reaching senior status. Students were coded a "1" for "graduated by summer after reaching senior status and completing the NSSE survey" or a "O" for "not graduated by summer after reaching senior status and completing the NSSE survey." This data was evaluated by minority status, first generation status, and low-income status. We defined minority as Black or African American, Hispanics of any race, Asian, two or more races, Native Hawaiian or other Pacific Islander, and American Indian or Alaska Native based on the Integrated Postsecondary Education Data System (IPEDS) definition. Those whose race and ethnicity was unknown were excluded from the analysis. First-generation students are those with neither parent having graduated with a bachelor's degree from a 4-year college or university. Low-income students are those who have ever received a Pell Grant based primarily on the student's or parents' income for the previous year.

\section{Data Analysis}

To address the research questions of this study, a quantitative method with several analytic approaches was adopted. Utilizing SPSS 26, we first examined the data before conducting data analysis to ensure the assumptions of multivariate analysis of variance (MANOVA) were met. Specifically, we checked multivariate normality, homogeneity of variance, outliers, and multicollinearity since multiple outcome variables were involved. Examinations of skewness and kurtosis (univariate and multivariate) were conducted for each engagement indicator, perceived gain, and satisfaction score. Analysis indicated no skewness or kurtosis appeared as skewness or kurtosis ranging from -3 to 3 (Kline, 2005). For homogeneity of variance, significance for Box's M Test is determined at $\alpha=0.001$ because this test is considered highly sensitive. Following Tabachnick and Fidell's suggestion (2013), we checked multicollinearity, and results indicated that neither of the two dependent variables of engagement indicators and perceived gains were correlated to each other above $r=0.90$. The bivariate correlation coefficients ranged from 0.125 to 0.552 among 10 engagement indicators and ranged from 0.414 to 0.739 among 10 perceived gains. Therefore, there is no evidence that multicollinearity existed between the set of variables of engagement, perceived gains, and satisfaction.

Second, we performed the General Linear Model (GLM) with two multivariate analyses of variance (MANOVAs) to examine the mean differences in engagement indicators and perceived gains between UGR participants and UGR non-participants since multiple composite scores of engagement indicators and perceived gains were examined (Stevens, 2002). The Bonferroni correction was applied to set the significance cut-off for alpha $(\alpha)$, in each case, at $0.005(0.05 / 10)$ since there were 10 dependent variables (10 engagement indicators and 10 perceived gains). In addition, one univariate analysis of variance was conducted to examine the mean difference in overall satisfaction between UGR participants and UGR non-participants. Two conditions that emerged from NSSE data require weighting that must be considered when conducting secondary analysis. One condition is when the proportion of respondents within a particular demographic variable (e.g., gender, full-time/part-time, or adult students) differs substantially from their population percentages. The second condition involves when students within a subgroup differ substantially in the variables of interest (e.g., full-time and part-time students may show different patterns of engagement and participation). Therefore, two sets of weight variables were pre-computed by NSSE for first-year and senior students, respectively,

Journal of the Scholarship of Teaching and Learning, Vol. 21, No. 1, April 2021. josotl.indiana.edu 
using gender and enrollment status information taken from submitted population files and were included in the data set released to the institution. In this study, weights for gender and full-time/parttime status for senior students were used for calculating means and standard deviations of engagement indicators, perceived gains, and overall satisfaction. The GLM over other procedures allowed the inclusion of sample weights when calculating means and standard deviations of the targeted variables and therefore was employed for the calculation (Chen et al., 2009; NSSE, n.d.).

Lastly, due to the categorical nature of persistence or graduation status ("persisted or graduated" versus "not persisted nor graduated"), we conducted the chi-squared test and logistics regression to address the fourth research question, "How does participation in UGR relate to persistence or graduation status controlling for gender, racial and ethnic minority, first-generation, and low-income status?" The chi-squared test can be used for testing dependence or homogeneity (Franke et al., 2012) and in this study was used to test the proportional differences between students who did and did not participate in UGR based on ethnic minority, first-generation, and low-income status. Hierarchical logistic regression was performed to test for the association of predictive variables with "persisted or graduated" status by adding them as a block to the model one at a time. We included the UGR participation status as one block of the variables, in addition to gender, race and ethnicity, first generation status, and low-income status as one block of control variables. These two blocks of variables were entered into the predictive equation in a hierarchical order to examine which variables significantly predict the outcome variable of persistence or graduation status with an additional block of variables introduced. For the chi-squared test and logistic regression, the alpha level for statistical significance was set at 0.05 .

\section{Limitations}

We acknowledge the limitations of the study. First, due to the lack of availability of institutional data from other similar campuses, the study focuses on the examination of UGR on student outcomes in one teaching-focused, minority-serving institution. Institutional collaboration for cross-institutional comparisons of student engagement in UGR would help illuminate the reproducibility of the results. Second, the small sample size of UGR participants (13\% of the survey-takers) could lead to bias in the results, which means there are not large enough numbers of each racial and ethnic group to allow for the examination of individual racial and ethnic groups. Future examination of the participation patterns of each individual racial and ethnic group by including more participants from each group or merging multiple years of NSSE data will extend current findings. Third, the study relies on selfreported measures of UGR, engagement, perceived gains, and overall satisfaction. Although NSSE relies on self-reported data, we do see a difference between UGR participants and non-participants in terms of persistence and graduation, suggesting the self-reported data is valid and reliable. Validated measures of students' actual participation were not available but would clearly add to the reliability of this study. Future studies may include data from other sources and/or collect more qualitative data to triangulate with quantitative measures (McNair \& Finley, 2013). Fourth, although the data of this study were collected in participants' senior year, the participation of UGR did not necessarily happen only in the senior year. However, this study provides an informative snapshot of student experience with UGR by senior year.

\section{Results}

We organized the results into three sections. Section I presents the results of engagement by UGR participation. Section II follows with results of perceived gains and overall satisfaction by UGR participation. Section III presents persistence or graduation results by disaggregating and comparing

Journal of the Scholarship of Teaching and Learning, Vol. 21, No. 1, April 2021.

josotl.indiana.edu 
the results by UGR participation and minority status, first-generation status, and low-income status, respectively. This section also includes the logistic regression results of persistence or graduation status on UGR participation, controlling for gender, race and ethnicity, first-generation status, and lowincome status.

\section{Engagement by UGR Participation}

In terms of engagement, there was a significant multivariate effect for engagement indicators between UGR participants and UGR non-participants, $F(10,1161)=12.30, p<0.001$. UGR participants had significantly higher mean scores on all of the engagement indicators than their UGR non-participants, ps $<0.005$ (see Table 1 and Figure 1).

Table 1. Means and standard deviations of engagement indicators by UGR participation status

\begin{tabular}{lllllll}
\hline Engagement & \multicolumn{7}{l}{ No UGR } & UGR & & \\
& $M^{a}$ & $S D$ & $M^{a}$ & $S D$ & $F$ & $0.002^{*}$ \\
\hline Higher-Order Learning & 43.87 & 13.20 & 47.26 & 10.85 & 9.78 & $0.001^{* *}$ \\
Reflective and Integrative Learning & 40.53 & 12.18 & 45.97 & 11.21 & 28.93 & $0.001^{* *}$ \\
Learning Strategies & 42.62 & 13.85 & 46.43 & 11.84 & 11.10 & $0.001^{* *}$ \\
Quantitative Reasoning & 28.12 & 16.03 & 36.10 & 16.02 & 35.08 & $0.001^{* *}$ \\
Collaborative Learning & 30.71 & 14.89 & 37.03 & 13.98 & 25.95 & 0.013 \\
Discussions with Diverse Others & 43.86 & 16.44 & 48.64 & 14.23 & 12.42 & $0.001^{* *}$ \\
Student-Faculty Interaction & 20.01 & 15.18 & 33.44 & 16.86 & 107.32 & $0.001^{* *}$ \\
Effective Teaching Practices & 42.11 & 14.54 & 45.86 & 12.08 & 9.86 & $0.002^{*}$ \\
Quality of Interactions & 42.88 & 13.28 & 46.60 & 11.07 & 11.64 & $0.001^{* *}$ \\
Supportive Environment & 31.70 & 14.78 & 37.25 & 14.62 & 20.07 & $0.001^{* *}$ \\
\hline
\end{tabular}

a. Weighted Least Squares Regression - Weighted by Gender, FT/PT weight for FY, SR within the institution. $* p<0.005$ (alpha was set at 0.005 , which is 0.05 divided by the number of ANOVAs conducted. It equals to the number of dependent variables, 10 in this case), ${ }^{* *} p<0.001$.

Journal of the Scholarship of Teaching and Learning, Vol. 21, No. 1, April 2021.

josotl.indiana.edu 


\section{Engagement Indicators by UGR Participation}

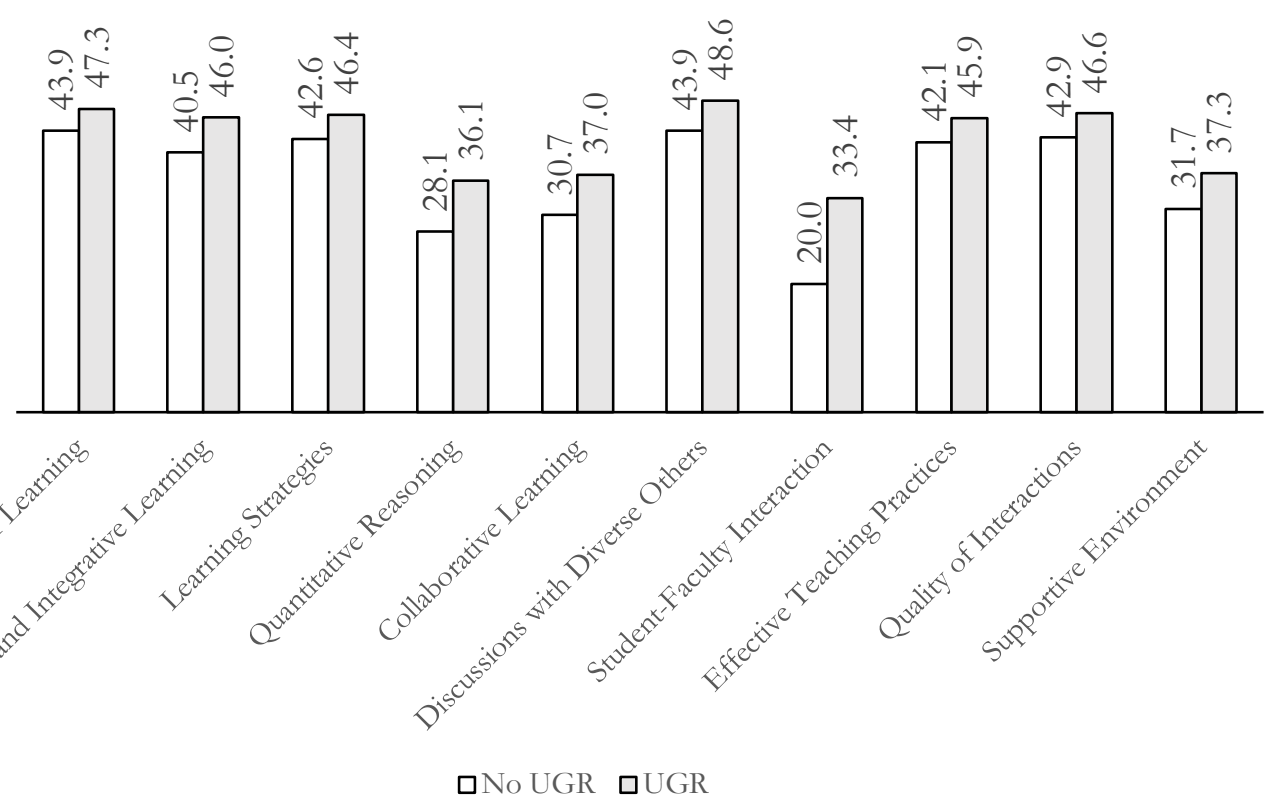

Figure 1. Engagement indicators by UGR participation. Average response scores to each question of the NSSE related to engagement is shown.

\section{Perceived Gains and Overall Satisfaction by UGR Participation}

Regarding perceived gains, there was a significant multivariate effect for perceived gains between UGR participants and UGR non-participants, $F(10,1322)=4.64, p<0.001$. UGR participants reported significantly higher scores on almost all of the perceived gains than their UGR non-participants, $p s<$ 0.001, except "Developing or clarifying a personal code of values and ethics" (see Table 2 and Figure 2). Similarly, there was a significant multivariate effect for perceived gains between UGR participants and UGR non-participants, $F(1,1394)=12.33, p<0.001$. UGR participants reported a significantly higher level of overall satisfaction than their UGR non-participants, $p<0.001$ (see Table 2 and Figure 2).

Table 2. Means and standard deviations of perceived gains and overall satisfaction by UGR participation status

\begin{tabular}{|c|c|c|c|c|c|c|}
\hline \multirow[t]{2}{*}{ Perceived gains } & \multicolumn{2}{|c|}{ No UGR } & \multicolumn{2}{|l|}{ UGR } & \multirow[b]{2}{*}{ F } & \multirow[b]{2}{*}{$p$} \\
\hline & $M^{a}$ & $S D$ & $M^{a}$ & $S D$ & & \\
\hline Writing clearly and effectively & 40.69 & 17.73 & 46.25 & 15.96 & 15.71 & $0.001 * *$ \\
\hline Speaking clearly and effectively & 37.52 & 18.96 & 43.56 & 16.87 & 16.25 & $0.001 * *$ \\
\hline Thinking critically and analytically & 45.85 & 15.96 & 52.05 & 11.58 & 25.10 & $0.001 * *$ \\
\hline $\begin{array}{l}\text { Analyzing numerical and statistical } \\
\text { information }\end{array}$ & 35.37 & 19.97 & 44.72 & 16.88 & 35.53 & $0.001 * *$ \\
\hline $\begin{array}{l}\text { Acquiring job-or work-related knowledge } \\
\text { and skills }\end{array}$ & 39.31 & 19.67 & 44.63 & 17.63 & 11.72 & $0.001 * *$ \\
\hline Working effectively with others & 40.06 & 18.09 & 45.06 & 16.39 & 12.22 & $0.001 * *$ \\
\hline $\begin{array}{l}\text { Developing or clarifying a personal code of } \\
\text { values and ethics }\end{array}$ & 37.47 & 20.11 & 41.53 & 19.15 & 6.44 & 0.011 \\
\hline
\end{tabular}

Journal of the Scholarship of Teaching and Learning, Vol. 21, No. 1, April 2021. josotl.indiana.edu 


\begin{tabular}{lllllll}
\hline Understanding people of other backgrounds & 38.87 & 18.98 & 43.93 & 17.12 & 11.35 & $0.001^{* *}$ \\
Solving complex real-world problems & 37.43 & 19.30 & 44.38 & 16.88 & 20.88 & $0.001^{* *}$ \\
Being an informed and active citizen & 34.60 & 20.21 & 40.59 & 18.20 & 14.06 & $0.001^{* *}$ \\
& & & & & & \\
Overall satisfaction & 47.97 & 13.93 & 51.86 & 11.20 & 12.35 & $0.001^{* *}$ \\
\hline
\end{tabular}

a. Weighted Least Squares Regression - Weighted by Gender, FT/PT weight for FY, SR within the institution. ${ }^{* *} p<0.001$ (alpha was set at 0.005 , which is 0.05 divided by the number of ANOVAs conducted. It equals to the number of dependent variables, 10 in this case).

\section{Perceived Gains by UGR Participation}

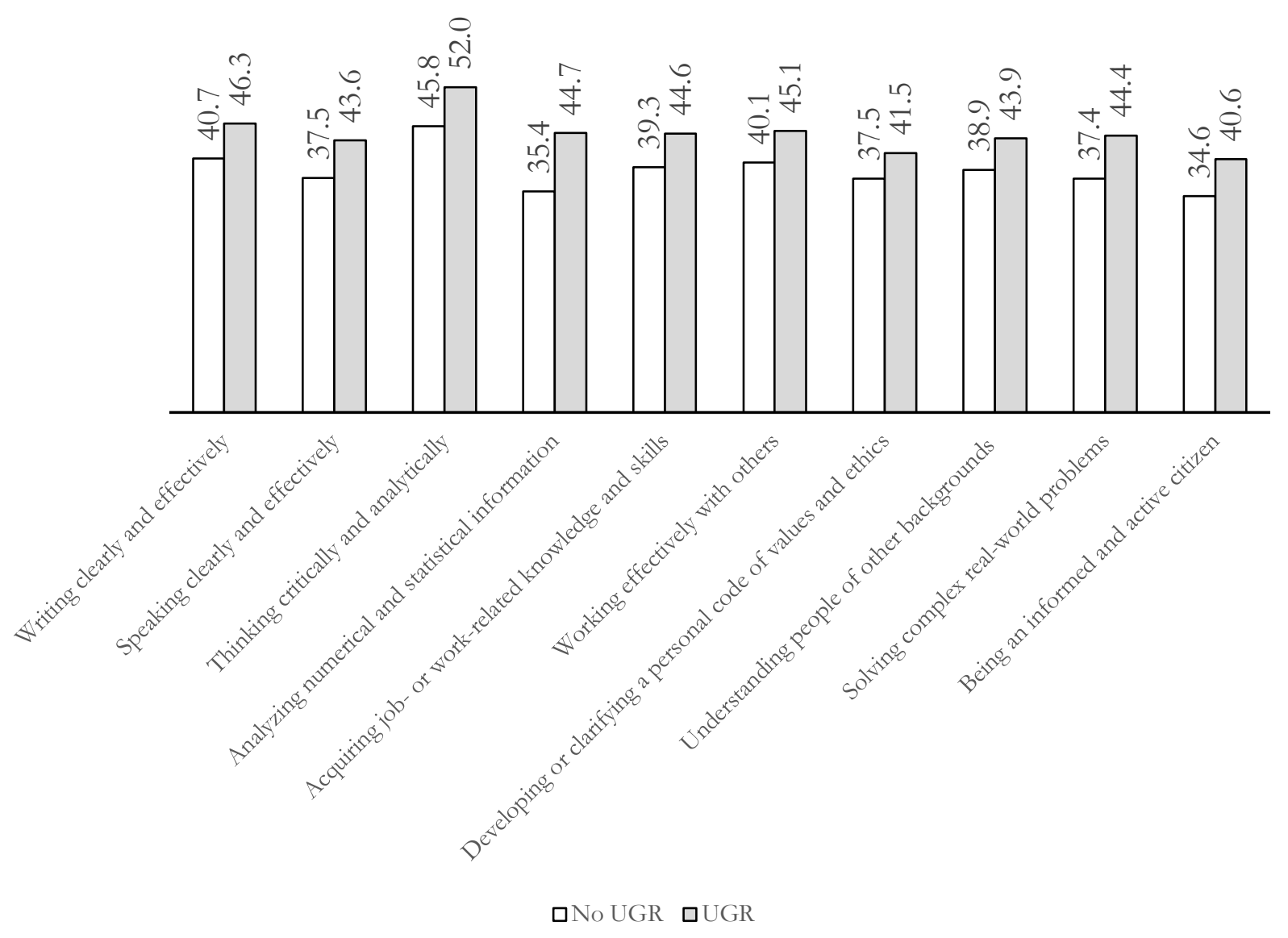

Figure 2. Perceived gains by UGR participation. Average response scores to each question of the NSSE related to perceived gains is shown.

\section{Persistence and Graduation Outcomes by UGR Participation}

Table 3 presents whether a student persisted (re-enrolled or graduated) (see Table 3 Column 4) and whether they graduated by summer after reaching senior status (see Table 3 Column 5) by UGR participation and race and ethnicity, first-generation status, and low-income status. Overall, there is a significantly larger proportion of UGR participants (95.4\%) still enrolled or graduated than their peer counterparts of UGR non-participants $(88.3 \%)$. The trends hold true when disaggregating the results 
by minority, first-generation, and low-income status. A significantly larger proportion of UGRparticipating students graduated compared to their non-participating peers, regardless of firstgeneration status or low-income status. Although ethnic minority UGR participants persisted at a higher rate $(91.8 \%)$ than UGR non-participants $(87.9 \%)$ (see Table 3, Column 4), the proportional difference was not significant.

Table 3. Persistence or graduation by UGR participation, race/ethnicity, first-generation, and low-income status

\begin{tabular}{|c|c|c|c|c|}
\hline & $\begin{array}{l}\text { UGR } \\
\text { Participation }\end{array}$ & Total & $\begin{array}{l}\text { Persisted } \\
\text { (Re-enrolled or Graduated) }\end{array}$ & Graduated \\
\hline \multirow[t]{4}{*}{ Overall } & No & 1,278 & $1129(88.3 \%)$ & $441(34.5 \%)$ \\
\hline & Yes & 194 & $185(95.4 \%)$ & $117(60.3 \%)$ \\
\hline & Total & 1,472 & 1,314 & 558 \\
\hline & Statistical test & & $\chi^{2}(1)=8.66, p<0.01$ & $\chi^{2}(1)=47.64, p<0.01$ \\
\hline \multirow[t]{4}{*}{ Minority } & No & 569 & $500(87.9 \%)$ & $196(34.4 \%)$ \\
\hline & Yes & 97 & $89(91.8 \%)$ & $48(49.5 \%)$ \\
\hline & Total & 666 & 589 & 244 \\
\hline & Statistical test & & $\chi^{2}(1)=1.22, p>0.05$ & $\chi^{2}(1)=8.07, p<0.01$ \\
\hline \multirow{4}{*}{$\begin{array}{l}\text { Non- } \\
\text { Minority }\end{array}$} & No & 672 & $596(88.7 \%)$ & $238(35.4 \%)$ \\
\hline & Yes & 92 & $91(98.9 \%)$ & $65(70.7 \%)$ \\
\hline & Total & 764 & 687 & 303 \\
\hline & Statistical test & & $\chi^{2}(1)=9.33, p<0.01$ & $\chi^{2}(1)=41.98, p<0.01$ \\
\hline \multirow{4}{*}{$\begin{array}{l}\text { First- } \\
\text { Generation }\end{array}$} & No & 825 & $729(88.4 \%)$ & $293(35.5 \%)$ \\
\hline & Yes & 129 & $122(94.6 \%)$ & $76(58.9 \%)$ \\
\hline & Total & 954 & 851 & 369 \\
\hline & Statistical test & & $\chi^{2}(1)=4.47, p<0.05$ & $\chi^{2}(1)=25.75, p<0.01$ \\
\hline \multirow{4}{*}{$\begin{array}{l}\text { Non-First- } \\
\text { Generation }\end{array}$} & No & 453 & $400(88.3 \%)$ & $148(32.7 \%)$ \\
\hline & Yes & 65 & $63(96.9 \%)$ & $41(63.1 \%)$ \\
\hline & Total & 518 & 463 & 189 \\
\hline & Statistical test & & $\chi^{2}(1)=4.45, p<0.05$ & $\chi^{2}(1)=22.68, p<0.01$ \\
\hline \multirow[t]{4}{*}{ Low-Income } & No & 652 & $600(92.0 \%)$ & $257(39.4 \%)$ \\
\hline & Yes & 124 & $118(95.2 \%)$ & $75(60.5 \%)$ \\
\hline & Total & 776 & 718 & 332 \\
\hline & Statistical test & & $\chi^{2}(1)=1.48, p>0.05$ & $\chi^{2}(1)=18.89, p<0.01$ \\
\hline \multirow{4}{*}{$\begin{array}{l}\text { Non-Low- } \\
\text { Income }\end{array}$} & No & 626 & $529(84.5 \%)$ & $184(29.4 \%)$ \\
\hline & Yes & 70 & $67(95.7 \%)$ & $42(60.0 \%)$ \\
\hline & Total & 696 & 596 & 226 \\
\hline & Statistical test & & $\chi^{2}(1)=6.42, p<0.05$ & $\chi^{2}(1)=26.90, p<0.01$ \\
\hline
\end{tabular}

Regarding institutional outcomes, overall, we observed an increase in persistence for UGR participants vs. UGR non-participants. For seniors who participated in UGR, a significantly larger proportion graduated by summer after reaching senior status or re-enrolled in the next fall $(95.4 \%)$ compared to their peers who did not participate in UGR $(88.3 \%), \chi^{2}(1)=8.66, p<0.01$, phi $=0.07$. The overall persistence boost is $7.1 \%$ for UGR participants against UGR non-participants (see Table 3 Column 4). The trends hold true for all subgroups examined, including minority, first-generation, and low-income students. A significantly higher proportion of students who participated in UGR 
persisted or graduated than their UGR non-participants, regardless of race and ethnicity, firstgeneration status, and low-income status (see Table 3, Column 4 and Figure 3).

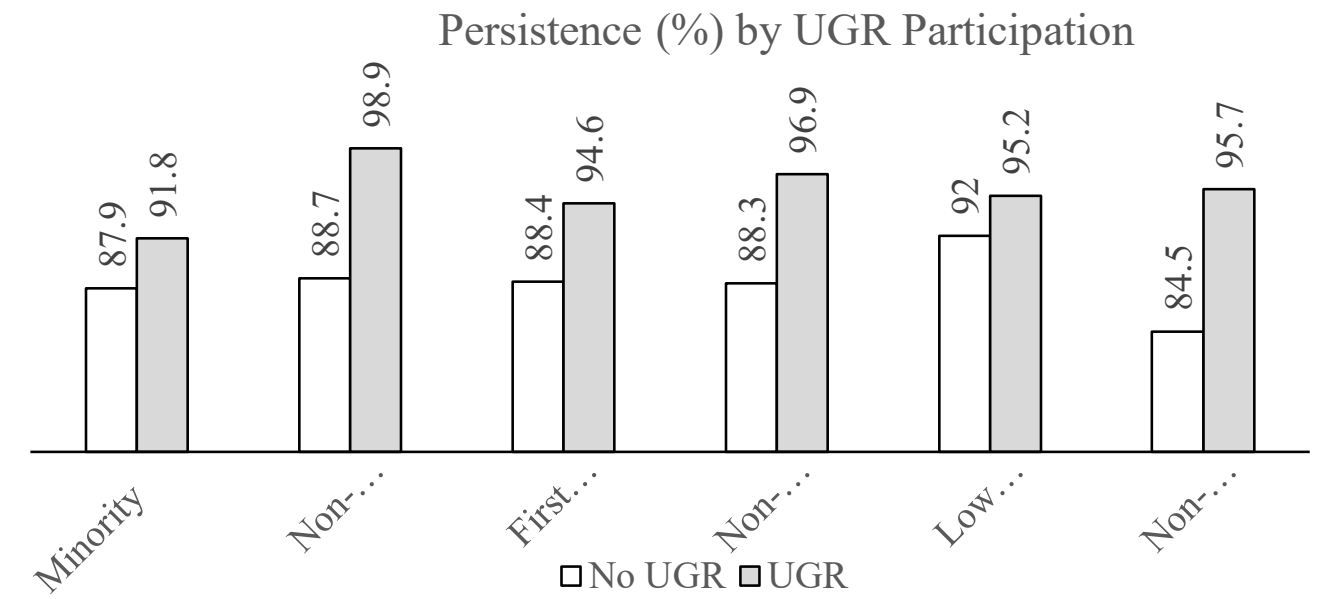

Figure 3. Persistence Outcomes by UGR Participation.

Similarly, overall, we observed higher rates of graduation for UGR participants compared to non-participants. For seniors who participated in UGRs, a significantly larger proportion graduated by summer after reaching senior status and completing the NSSE survey $(60.3 \%)$ compared to their peers who did not participate in UGR $(34.5 \%), \chi^{2}(1)=47.64, p<0.01$, phi $=0.18$ (see Table 3 Column $5)$. This was true across all subgroups examined, regardless of minority, first-generation, or lowincome status (see Figure 4).

Graduation (\%) by UGR Participation

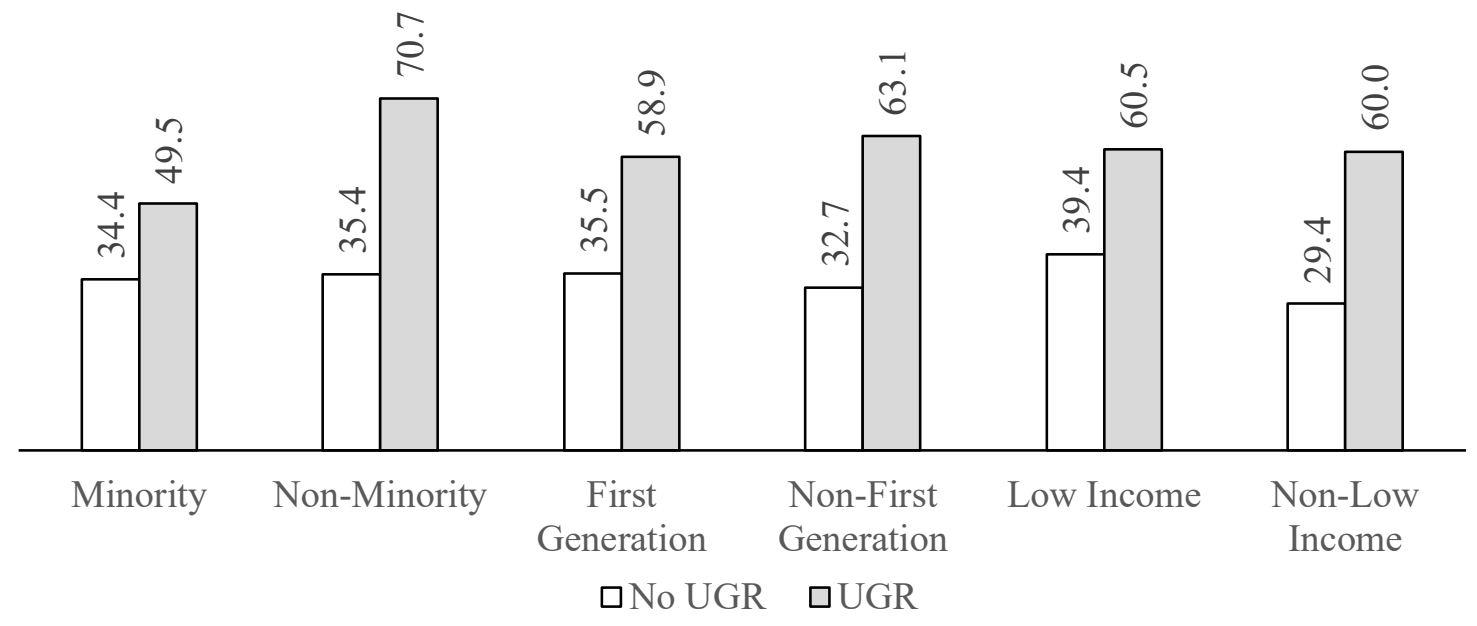

Figure 4. Graduation Outcomes by UGR Participation. 
A logistic regression was conducted for persistence (fall to fall re-enrollment or graduation by summer after NSSE administration) on UGR participation controlling for gender, race and ethnicity, first-generation status, and low-income status. After controlling for other variables, the results indicated that UGR participation was a significant predictor of persistence, Wald $F(1)=6.93, p<0.01$ (see Table 4). This indicates that there is a positive relationship between UGR participation and persistence. If a student participated in UGR, the odds of this student persisting would increase by 155 percent. First-generation status was also a significant predictor of persistence status, Wald $F(1)=$ $16.11, p<0.01$ (see Table 4). Being a first-generation student, the odds of that student being retained or graduated would increase by 105 percent. Gender, race and ethnicity, and low-income status were not significant predictors of retention or graduation status, Wald $F(1)=2.77,1.788$, and 0.186 , ps $>$ 0.05 , respectively (see Table 4 ).

Table 4. Regression results of retention or graduation status on UGR participation (controlling for other variables).

\begin{tabular}{lllllll}
\hline & $\mathrm{B} \dagger$ & $\mathrm{SE} \ddagger$ & Wald $\Omega$ & $\mathrm{df**}$ & $p+\dagger$ & $\mathrm{Exp}(\mathrm{B})$ 杆 \\
\hline Gender & -0.336 & 0.202 & 2.770 & 1 & 0.096 & 0.715 \\
Ethnic Minority & -0.232 & 0.173 & 1.788 & 1 & 0.181 & 0.793 \\
First-Generation Status & 0.718 & 0.179 & $\mathbf{1 6 . 1 1} \Omega \mathbb{S}$ & 1 & $\mathbf{0 . 0 0 1}$ & $\mathbf{2 . 0 5 0}$ \\
Low-Income Status & -0.079 & 0.183 & 0.186 & 1 & 0.666 & 0.924 \\
& & & & & & \\
UGR & 0.935 & 0.355 & $\mathbf{6 . 9 2 8}$ & 1 & $\mathbf{0 . 0 0 8}$ & $\mathbf{2 . 5 4 8}$ \\
Constant & 1.934 & 0.183 & 111.272 & 1 & 0.001 & 6.920 \\
\hline
\end{tabular}

* Hierarchical linear regression is a statistical technique that tests for the influence variables by adding them to the model one at a time.

† B lists the partial logistic regression coefficients for each independent variable.

$\ddagger$ S.E. or standard error measures the accuracy with which a sample represents a population.

$\int$ Wald is a way of testing the significance of independent variables in a statistical model.

** $\mathrm{df}$ or degree of freedom is the number of values in the study that are free to vary.

$\mathrm{H} p$ is an estimate of the probability that the result occurred by statistical accident. A low level of $p$ indicates a high level of statistical significance.

柱 $\operatorname{Exp}(\mathrm{B})$ list the odds ratios, which are used to assess the isolated impact of each independent variable.

$\int \$$ Bold indicates statistically significant results.

\section{Discussion}

\section{The Relationship between UGR Participation and Engagement}

UGR participants reported significantly higher scores on all of the engagement indicators compared to their UGR non-participants. Their multiple and positive experiences with the four NSSE engagement themes (i.e., being academically challenged, learning with peers, working with faculty, and having a supportive environment to thrive) were reflected in their responses. Notably, students reported higher scores of student-faculty interactions, quantitative reasoning, and collaborative learning experiences (13.4, 8.0, and 6.3 higher for UGR participants compared to non-participants, respectively, see Table 1 and Figure 1). This is important because these represent relationship-building and skills-development that can contribute to persistence, completion, and improved performance in graduate school or the workforce. UGR opportunities promote teamwork where students can learn from one another and employ collaboration and communication skills in authentic situations that they wouldn't otherwise practice in a classroom, and this is reflected in the 6.3 increase of reported experience with collaborative learning. Students must contribute collectively, as well as be held 
accountable to accomplish tasks independently when engaged in research teams (Madan \& Teitge, 2013). Whether students choose to go on to graduate school or join the workforce upon graduation, knowing how to work in teams and communicate with diverse colleagues are highly valued skills (Baird \& Parayitam, 2019).

In addition, these results confirm that UGR requires participants to use higher order thinking and metacognitive skills (UGR participants reported 3.4 higher gains in higher order learning and 5.5 gains in reflective and integrative learning, respectively, compared to non-participants). In conducting research, students have to collect, apply, analyze, and synthesize, as well as interpret and evaluate information that is being studied. The direct impact of UGR on metacognition has been reported by Dahlberg et al. (2019) and Kortz and van der Hoeven Kraft (2016), but this NSSE data from seniors implies that the gains are recognized by the student participants and persist to the senior year, even if the research happened previously. Too often institutions of higher education are criticized for not facilitating the development of higher order thinking skills among students (Arum \& Roksa, 2011), but UGR may be a way to ensure students hone these skills.

Lastly, the 13.4 gain in UGR participants reports of student-faculty interaction compared to non-participants is worth celebrating. One of the most important factors in students' success in college is their interactions with faculty (Anaya \& Cole, 2001; Campbell \& Campbell, 1997; Chickering \& Gamson, 1987; DeAngelo et al., 2016; Eagan et al., 2013). Students who participate in UGR have regular and meaningful interactions with faculty (Taraban \& Logue, 2012). Students who work with a faculty mentor achieve higher academic performance, gain networking opportunities and feel welcomed into the discipline, and develop confidence (DeAngelo et al., 2016). These interactions are especially important for underrepresented minority students who may have an increased sensitivity to mentoring relationships (Jones et al., 2010; Lopatto, 2004). That UGR facilitates such increased perception of these interactions at a teaching institution, where research is likely occurring in nontraditional ways, is note-worthy.

\section{The Relationship between UGR Participation and Perceived Gains and Overall Satisfaction}

UGR participants reported significantly higher scores on almost all of the perceived gains compared to UGR non-participants and had significantly higher levels of overall satisfaction (the only gain that was not significantly increased was "developing or clarifying a personal code of values and ethics", see Table 2). Notably, UGR participants had higher gains compared to their non-participant peers in analyzing numerical and statistical information (9.3 point gain), solving complex real-world problems (7 point gain), thinking critically and analytically (6.2 point gain), and being an informed and active citizen (6 point gain) (see Table 2). In today's day and age, we think all efforts that increase these metrics in students should be employed.

Students who participated in UGR positively evaluated their educational experiences, said they would go to the same institution if they had to start over, and reported positive relationships with peers, advisors, faculty, staff, and students (data not shown). Participating in UGR promotes perceived gains in personal (e.g., understanding people of different backgrounds), practical (e.g., working effectively with others), and general education competency (e.g., solving complex real-world problems) areas, as well as higher satisfaction in their educational experience. These types of gains had been documented in both an apprentice-type research experience and a CURE (Kinner \& Lord, 2018; Williams et al., 2016), though both these previous reports focused exclusively on self-reported gains immediately after a single STEM course or summer research experience at a research university. We demonstrate that these gains occur at teaching institutions and potentially persist far beyond the actual UGR experience.

Journal of the Scholarship of Teaching and Learning, Vol. 21, No. 1, April 2021. josotl.indiana.edu 
The Relationship between UGR and Persistence and Graduation Disaggregated by Race and Ethnicity, First-generation Status, and Low-income Status

Participating in UGR positively impacts persistence (re-enrollment or graduation by the fall following NSSE administration) or graduation. In this study, a significantly higher proportion of students who participated in UGR graduated within one year of becoming a senior $(60.3 \%)$ than non-participants $(35.4 \%)$. This trend was true regardless of minority, first-generation, or low-income status. These findings corroborate studies noted earlier in the paper; working on novel research with a faculty member positively impacts student retention and graduation (Eagan et al., 2013; Lopatto, 2010; Seymour

et

al., 2004).

It is worth noting that we did observe a significant racial equity gap in the impact of UGR when it comes to persistence and graduation. While an admirable $91.8 \%$ of UGR participating racial and ethnic minority students persisted, the percent of non-minority UGR participants that persisted was $98.9 \%$ (Table 3 Column 4, and Figure 3). Even more startling is the fact that only 49.5\% of minority UGR-participants in our data set graduated by summer after reaching their senior status, compared to 70.7\% non-minority UGR-participants (Table 3 Column 5, and Figure 4). The "boost" in persistence and graduation rates for non-minority students is significantly higher than it is for minority students (see Figure 5). While we cannot eliminate the possibility that there were compounding factors that could impact this data, such as unique disciplinary differences, we suspect the data is straightforward: minority students face additional obstacles that opportunities like UGR are not sufficient in eliminating. Interestingly, there was almost no gap in graduation rates between low-income and non-low-income UGR participants $60.5 \%$ compared to $60.0 \%$ respectively, see Figure 4), so the racial equity gap may not be due to intersecting economic barriers. Similarly, there was only a small difference in the percent of UGR-participating first-generation students that graduated within a year of starting their senior year (58.1\%) compared to non-first-generation students (63.1\%). As teaching institutions develop additional UGR opportunities, it is critical that faculty and administrators evaluate the literature on how best to support, retain, and graduate minority students.

\section{Boost in Persistence (\%) and Graduation (\%) from UGR Participation}

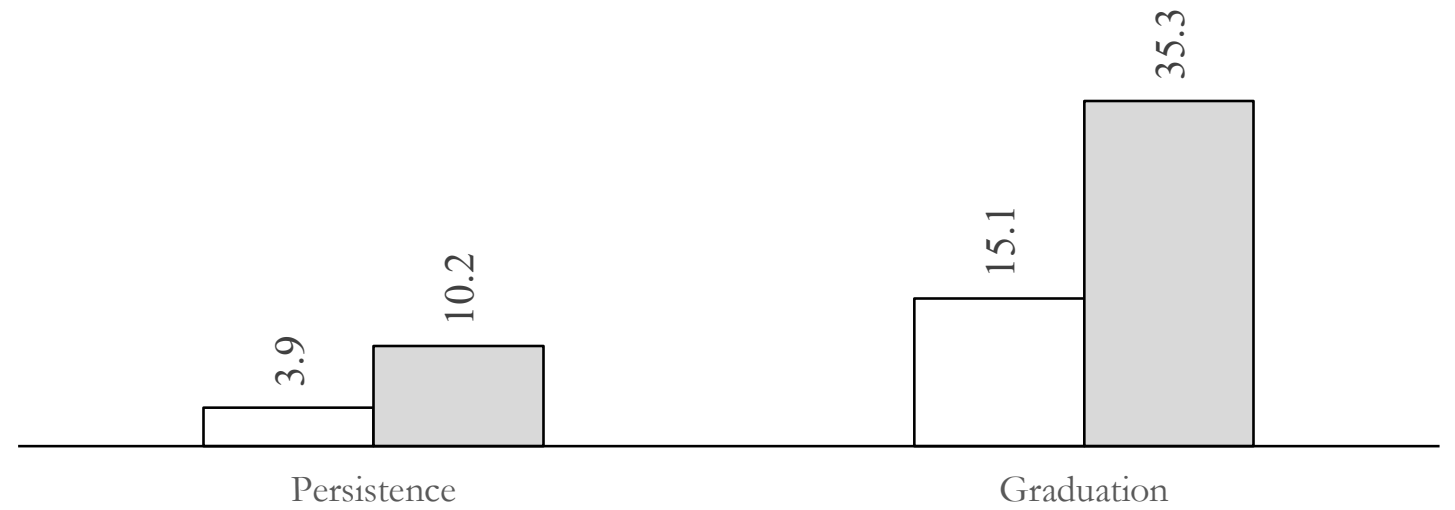

Minority $\square$ Non-Minority

Figure 5. Persistence and Graduation Boost by UGR Participation for Minority and NonMinority.

Journal of the Scholarship of Teaching and Learning, Vol. 21, No. 1, April 2021. josotl.indiana.edu 


\section{Overall Impact of UGR}

UGR is positively associated with higher perceived gains, satisfaction, persistence, and graduation. We recognize that we cannot conclude that UGR causes improved outcomes, as students that are more likely to be engaged or satisfied or likely to persist/graduate could be more likely to participate in UGR. Indeed, Webber and colleagues (2013) reported that some students (i.e., students in STEM, students participating in Greek life, students attending full-time, and students with higher GPAs) were somewhat more likely to participate in UGR. However, Fechheimer and colleagues (2011) have shown that participation in research-based classes at a research university led to significant increases in academic success outcomes, even when they controlled for SAT scores - a measure of academic ability prior to the UGR experience. This contradicts an explanation of more engaged or capable students selecting UGR and thus performing better. Although we cannot claim causality, there is clearly a positive relationship between UGR and academic success/completion, and this has implications at different levels. As stated earlier, there is a dearth of literature on why students do not participate in research. Lack of time (Stout, 2018), working a significant number of hours outside of school (Falcon, 2015; RTI International, 2019), and challenges balancing between time and research are cited in the literature. Because the gains for students are so large and so consistent, we would argue that teaching colleges continue to find ways to involve more students in UGR or reduce/eliminate barriers to these activities (several suggested mechanisms are discussed below). Still, the impacts of these activities at this institution were higher for non-minority students, and thus additional interventions to support these students must be considered. Future studies should increase the sample size so individual racial/ethnic groups can be examined. In addition, qualitative interviewing/focus groups of minority students to understand why gains from UGR participation are not equal in terms of persistence and graduation would be useful.

\section{Approaches Teaching-Centered Colleges Can Take to Enhance UGR}

One of the easiest ways for teaching-centered colleges to curate additional UGR opportunities is to embrace existing CUREs that are intended to be reproduced and in fact leverage crowd-sourced data from multiple institutions. These are most commonly in the sciences and are aimed at introductorylevel courses, making them accessible even at community colleges. For example, the Howard Hughes Medical Institute's Science Education Alliance (SEA) has both a PHAGES program and subsequent GENES program to characterize novel bacteriophages and is open to all 2-year and 4-year institutions (https://www.hhmi.org/science-education/programs/science-education-alliance). Yale University created the Small World Initiative, www.smallworldinitiative.org, which boasts an international network to curate the world's next highly-needed antibiotics. These programs offer resources and support for faculty joining these projects. While limited, some entities are trying to curate existing CURE projects, such as CureNet (https://serc.carleton.edu/curenet/index.html), which can be a resource for teaching institution faculty, as well.

There are promising opportunities for the humanities and social sciences to embed research in their courses, as well. For example, for those in psychology, the Collaborative Replications and Education Project (https://osf.io/wfc6u/) strives to find groups, such as classes, to reproduce highlycited studies, and the Emerging Adulthood Measured at Multiple Institutions project (https://osf.io/te54b/) seeks new collaborators to help investigate attitudes, behaviors, and beliefs related to emerging adulthood. General faculty can visit Zooniverse.org to find 25 crowd-sourced data projects that their students can engage with and discuss, from transcribing supreme court justice's hand-written notes or tracking the life histories of historical criminals to classifying baby speech sounds (Zooniverse.org). The Council on Undergraduate Research (www.cur.org), while requiring

Journal of the Scholarship of Teaching and Learning, Vol. 21, No. 1, April 2021. josotl.indiana.edu 
membership, has archived highlights of collaborative undergraduate research projects in broad disciplines from the arts and humanities to social sciences to engineering. Others have published about course-based methods in community-based surveys for social science courses (Crowe \& Boe, 2019), as well as the use of existing databases or community-generated data for research in introductory statistics courses (Le, 2020). At our Institution, faculty in Psychology leverage methodology courses to implement short but authentic research projects among student groups.

Inspiration can be found nationally and locally for increasing research opportunities. Community colleges can gain inspiration from the Community College Undergraduate Research Initiative (https://www.ccuri.org/), which has established a large network across the country to develop opportunities for research. Research experiences range from field work and laboratory investigations to interview transcription, recording and data entry, or basic analyses requiring what would be expected in a collegiate statistics course. Even the use of student workers as research assistants can be a modern modification to the traditional apprentice model. In all disciplines, there is also the opportunity for local collaboration to undergird novel experiences for students: community colleges can partner with local research institutes, and professional school faculty (such as those in Education or Nursing) can collaborate with local organizations (schools, hospitals, non-profits, etc.) to engage in action research.

Administrative support is also critical to the initiation and success of undergraduate research at teaching-centered colleges. At our institution, the Provost provided seed-funding awards for faculty scholarship that involved students and provided compensation for several faculty to engage in a summer institute to construct/revamp courses to embed scholarly research. For example, this enabled a history faculty member to develop a collaboration with a local fire department to create a multisemester project for students to archive and research unique materials, untouched for fifty years, from firehouse storage. Centralized support for grant writing and submission, library resources with sufficient staff and adequate access to materials, travel support for sharing work, and recognition and compensation for faculty mentoring of undergraduate researchers are also ways administration can facilitate growth in UGR at teaching-centered institutions and community colleges (Marwick, 2012). While curriculum is a product of the faculty, there are certainly ways in which the administration can collaborate with faculty on curricular requirements for UGR and support faculty in course redesign. Policies can be generated that allow faculty to leverage independent study projects with students into future course releases. Studies have shown faculty are willing and eager to engage with students in activities like UGR, but in the end, administrators are key in ensuring that the benefits to faculty reflect the subsequent benefits to students and facilitate their choices to make greater UGR opportunities a reality (Eagan et al, 2011).

\section{Conclusion}

In this study, we sought to examine whether there were differences in seniors' level of engagement, perceived gains, and overall satisfaction relative to their participation in UGR in a regional, comprehensive institution. Additionally, the extent to which participation in UGR impacted persistence and graduation after reaching the senior year was explored. The findings yielded positive results in all outcomes, demonstrating the importance of UGR at teaching-centered institutions.

Undergraduate research can be implemented and leveraged at teaching-focused colleges to enhance the student experience, as well as assist in critical persistence and graduation imperatives. Teaching colleges can and should embrace a variety of UGR methods, from CUREs to modified credit-bearing apprenticeship models with flexibility for diverse student needs. Faculty across disciplines could be encouraged to embed authentic inquiry experiences in their classes to increase their students' knowledge and skills in research. While selected disciplines in teaching colleges, for

Journal of the Scholarship of Teaching and Learning, Vol. 21, No. 1, April 2021.

josotl.indiana.edu 
example education and nursing, might have a more difficult time embedding research into their courses due to the high number of required clinical hours in the field and other licensure requirements, targeted professional development and mentoring could assist faculty in embedding meaningful research opportunities for students in their courses that would enhance the overall learning experience. While historically UGR has been more prominent at research institutions, many types of UGR can be adapted to teaching institutions, including CUREs, research internships for credit, and modified apprentice models where small numbers of students work directly with a faculty member on a study for credit. Colleges should find and fund mechanisms to help train faculty to build these kinds of courses and programs and support these programs with space and administrative support. The return on investment is clear: enhanced engagement, gains, satisfaction, persistence, and graduation, all of which will lead to more adaptive, qualified, and fulfilled alumni.

\section{Appendix}

\begin{tabular}{|c|c|c|}
\hline & Question in NSSE & Example Items \\
\hline \multicolumn{3}{|c|}{ I. Student Engagement Indicator } \\
\hline \multirow[t]{2}{*}{$\begin{array}{l}\text { Higher-Order } \\
\text { Learning }(\mathrm{HO})\end{array}$} & \multirow{2}{*}{$\begin{array}{l}\text { During the current school year, how much has your } \\
\text { coursewwork emphasized the following } \\
\text { (Very much, quite a bit, some, very little) }\end{array}$} & $\begin{array}{l}\text { Applying facts, theories, or methods to practical } \\
\text { problems or new situations }\end{array}$ \\
\hline & & $\begin{array}{l}\text { Analyzing an idea, experience, or line of reasoning in } \\
\text { depth by examining its parts }\end{array}$ \\
\hline \multirow{2}{*}{$\begin{array}{l}\text { Learning Strategies } \\
\text { (LS) }\end{array}$} & \multirow{2}{*}{$\begin{array}{l}\text { During the current school year, how often have you } \\
\text { (Very often, often, sometimes, never) }\end{array}$} & Identified key information from reading assignments \\
\hline & & $\begin{array}{l}\text { Summarized what you learned in class or from course } \\
\text { materials }\end{array}$ \\
\hline \multirow[t]{2}{*}{$\begin{array}{l}\text { Quantitative } \\
\text { Reasoning }(Q R)\end{array}$} & \multirow[t]{2}{*}{$\begin{array}{l}\text { During the current school year, how often have you } \\
\text { (Very often, often, sometimes, never) }\end{array}$} & $\begin{array}{l}\text { Reached conclusions based on your own analysis of } \\
\text { numerical information (numbers, graphs, statistics, } \\
\text { etc.) }\end{array}$ \\
\hline & & $\begin{array}{l}\text { Used numerical information to examine a real-world } \\
\text { problem or issue (unemployment, climate change, } \\
\text { public health, etc.) }\end{array}$ \\
\hline \multirow[t]{2}{*}{$\begin{array}{l}\text { Collaborative } \\
\text { Learning }(C L)\end{array}$} & \multirow[t]{2}{*}{$\begin{array}{l}\text { During the current school year, how often have you } \\
\text { (Very often, often, sometimes, never) }\end{array}$} & $\begin{array}{l}\text { Asked another student to help you understand course } \\
\text { material }\end{array}$ \\
\hline & & $\begin{array}{l}\text { Prepared for exams by discussing or working through } \\
\text { course material with other students }\end{array}$ \\
\hline \multirow{2}{*}{$\begin{array}{l}\text { Discussions with } \\
\text { Diverse Others (DD) }\end{array}$} & \multirow{2}{*}{$\begin{array}{l}\text { During the current school year, how often have you had } \\
\text { discussions with people from the following groups } \\
\text { (Very often, often, sometimes, never) }\end{array}$} & People from a race or ethnicity other than your own \\
\hline & & $\begin{array}{l}\text { People from an economic background other than your } \\
\text { own }\end{array}$ \\
\hline \multirow{2}{*}{$\begin{array}{l}\text { Student-Faculty } \\
\text { Interaction (SF) }\end{array}$} & \multirow{2}{*}{$\begin{array}{l}\text { During the current school year, how often have you } \\
\text { (Very often, often, sometimes, never) }\end{array}$} & Talked about career plans with a faculty member \\
\hline & & $\begin{array}{l}\text { Worked with a faculty member on activities other than } \\
\text { coursework (committees, student groups, etc.) }\end{array}$ \\
\hline \multirow{2}{*}{$\begin{array}{l}\text { Effective Teaching } \\
\text { Practices (ET) }\end{array}$} & \multirow{2}{*}{$\begin{array}{l}\text { During the current school year, to what extent have } \\
\text { your instructors done the following } \\
\text { (Very much, quite a bit, some, very little) }\end{array}$} & Clearly explained course goals and requirements \\
\hline & & $\begin{array}{l}\text { Used examples or illustrations to explain difficult } \\
\text { points }\end{array}$ \\
\hline \multirow{3}{*}{$\begin{array}{ll}\text { Quality } & \text { of } \\
\text { Interactions (QI) }\end{array}$} & \multirow{3}{*}{$\begin{array}{l}\text { Indicate the quality of your interactions with the } \\
\text { following people at your institution } \\
\text { (1: Poor to 7: excellent) }\end{array}$} & Students \\
\hline & & Academic advisors \\
\hline & & Faculty \\
\hline \multirow[t]{2}{*}{$\begin{array}{l}\text { Supportive } \\
\text { Environment (SE) }\end{array}$} & \multirow{2}{*}{$\begin{array}{l}\text { How much does your institution emphasize the } \\
\text { following (Very much, quite a bit, some, very } \\
\text { little) }\end{array}$} & $\begin{array}{l}\begin{array}{l}\text { Providing support to help students succeed } \\
\text { academically }\end{array} \\
\end{array}$ \\
\hline & & $\begin{array}{l}\text { Using learning support services (tutoring services, } \\
\text { writing center, etc.) }\end{array}$ \\
\hline \multicolumn{3}{|l|}{ II. Perceived Gains (PG) } \\
\hline & \multirow{2}{*}{$\begin{array}{l}\text { How much has your experiences at this institution } \\
\text { contributed to your knowledge, skills, and personal } \\
\text { development in the following areas? (Very much, } \\
\text { quite a bit, some, very little) }\end{array}$} & Writing clearly and effectively \\
\hline & & Acquiring job- or work-related knowledge and skills \\
\hline \multicolumn{3}{|c|}{ III. Overall Satisfaction (OS) } \\
\hline
\end{tabular}

Journal of the Scholarship of Teaching and Learning, Vol. 21, No. 1, April 2021. josotl.indiana.edu 


\begin{tabular}{|l|l|l|}
\hline Evaluation (EV) & $\begin{array}{l}\text { How would you evaluate your entire educational } \\
\text { experience at this institution? }\end{array}$ & Excellent, good, fair, and poor \\
\hline $\begin{array}{l}\text { Whether go to the } \\
\text { same institution (SI) }\end{array}$ & $\begin{array}{l}\text { Ifyou could start over again, would you go to the same } \\
\text { institution you are now attending? }\end{array}$ & Definitely yes, probably yes, probably no, definitely no \\
\hline
\end{tabular}

\section{References}

Anaya, G., \& Cole, D. G. (2001). Latina/o student achievement: Exploring the influence of studentfaculty interactions on college grades. Journal of College Student Development, 42(1), 3-14. Retrieved from https://www.researchgate.net/publication/285632628_Latinao_student_achievement_Expl oring_the_influence_of_student-faculty_interactions_on_college_grades

Arum, R., \& Roksa, J. (2011). Academically adrift: Limited learning on college campuses. Chicago, IL: University of Chicago Press.

Auchincloss, L. C., Laursen, S. L., Branchaw, J. L., Eagan, K., Graham, M., Hanauer, D. I., ... Dolan, E. L. (2014). Assessment of course-based undergraduate research experiences: A meeting report. CBE-Life Sciences Education, 13(1), 29-40. https://doi.org/10.1187/cbe.1401-0004

Baird, A. M., \& Parayitam, S. (2019). Employers' ratings of importance of skills and competencies college graduates need to get hired: Evidence from the New England region of USA. Education + Training, 61(5), 622-634. https://doi.org/10.1108/ET-12-2018-0250

Bangera, G., \& Brownell, S. E. (2014). Course-based undergraduate research experiences can make scientific research more inclusive. CBE-Life Sciences Education, 13(4), 602-606. https://doi.org/10.1187/cbe.14-06-0099

Brandt, L. S. E., \& Hayes, J. L. (2012). Broader impacts of undergraduate research at a community college: Opening doors to new ideas. Council on Undergraduate Research Quarterly, 33(1), 17-21. Retrieved from https://www.cur.org/assets/1/7/331Fall12Brandt.pdf

Campbell, T. A., \& Campbell, D. E. (1997). Faculty/student mentor program: Effects on academic performance and retention. Research in Higher Education, 38(6), 727-742. https://doi.org/10.1023/A:1024911904627

Carpi, A., Ronan, D. M., Falconer, H. M., \& Lents, N. H. (2017). Cultivating minority scientists: Undergraduate research increases self-efficacy and career ambitions for underrepresented students in STEM. Journal of Research in Science Teaching, 54(2), 169-194. https://doi.org/10.1002/tea.21341

Cejda, B. D., \& Hensel, N. H. (2009). Undergraduate research at community colleges. Washington, DC: Council on Undergraduate Research.

Center, N. R. (2017). Two-year contributions to four-year completions-2017. National Student Clearinghouse Research Center. Retrieved from https://nscresearchcenter.org/snapshotreport-twoyearcontributionfouryearcompletions26/

Chen, P. S. D., Gonyea, R. M., Sarraf, S. A., BrckaLorenz, A., Korkmaz, A., Lambert, A. D., ... Williams, J. M. (2009). Analyzing and interpreting NSSE data. New Directions for Institutional Research, 141, 35-43. doi: 10.1002/ir.285

Chickering, A. W., \& Gamson, Z. F. (1987). Seven Principles for Good Practice in Undergraduate Education. AAHE Bulletin. Retrieved from http://eric.ed.gov/?id=ED282491

Crowe, J., \& Boe, A. (2019). Integrating undergraduate research into social science curriculum: Benefits and challenges of two models. Education Sciences, 9(4), 1-13. doi:10.3390/educsci9040296 
Dahlberg, C. L., Wiggins, B. L., Lee, S. R., Leaf, D. S., Lily, L. S., Jordt, H., \& Johnson, T. J. (2019). A short, course-based research module provides metacognitive benefits in the form of more sophisticated problem solving. Journal of Science College Teaching, 48(4), 22-30. doi: 10.2505/4/jcst19_048_04_22

DeAngelo, L., Mason, J., \& Winters, D. (2016). Faculty engagement in mentoring undergraduate students: How institutional environments regulate and promote extra-role behavior. Innovative Higher Education, 41(4), 317-332. https://doi.org/10.1007/s10755-015-9350-7

Eagan, M. K., Hurtado, S., Chang, M. J., Garcia, G. A., Herrera, F. A., \& Garibay, J. C. (2013). Making a difference in science education: The impact of undergraduate research programs. American Educational Research Journal, 50(4), 683-713. https://doi.org/10.3102/0002831213482038

Eagan, M. K., Jr., Sharkness, J., Hurtado, S., Mosqueda, C. M., \& Chang, M. J. (2011). Engaging undergraduates in science research: Not just about faculty willingness. Research in higher education, 52(2), 151-177. https://doi.org/10.1007/s11162-010-9189-9

Falcon, L. (2015). Breaking down barriers: First-generation college students and college success. The Learning Assistance Review (TLAR), 17(2), 7-20. https:/ / files.eric.ed.gov/ fulltext/EJ1002281.pdf

Fechheimer, M., Webber, K., \& Kleiber, P. B. (2011). How well do undergraduate research programs promote engagement and success of students? CBE life sciences education, 10(2), 156163. https://doi.org/10.1187/cbe.10-10-0130

Franke, T. M., Ho, T., \& Christie, C. A. (2012). The chi-square test: Often used and more often misinterpreted. American Journal of Evaluation, 33(3), 448-458. https://doi.org/10.1177/1098214011426594

Gardner, J. N., \& Veer, G. V. der. (1998). The senior year experience: Facilitating integration, reflection, closure, and transition. San Francisco, CA: Jossey-Bass Publishers.

Harrison, M., Dunbar, D., Ratmansky, L., Boyd, K., \& Lopatto, D. (2011). Classroom-based science research at the introductory level: Changes in career choices and attitude. CBE-Life Sciences Education, 10(3), 279-286. https://doi.org/10.1187/cbe.10-12-0151

Hathaway, R. S., Nagda, B. (Ratnesh) A., \& Gregerman, S. R. (2002). The relationship of undergraduate research participation to graduate and professional education pursuit: An empirical study. Journal of College Student Development, 43(5), 614-631. doi: 10.1353/jhe.2015.0031

Hu, S., Kuh, G. D., \& Gayles, J. G. (2007). Engaging undergraduate students in research activities: Are research universities doing a better job? Innovative Higher Education, 32(3), 167-177. https://doi.org/10.1007/s10755-007-9043-y

Hurtado, S., Newman, C. B., Tran, M. C., \& Chang, M. J. (2010). Improving the rate of success for underrepresented racial minorities in STEM fields: Insights from a national project. New Directions for Institutional Research, 2010(148), 5-15. https://doi.org/10.1002/ir.357

Jones, M. T., Barlow, A. E. L., \& Villarejo, M. (2010). Importance of undergraduate research for minority persistence and achievement in biology. The Journal of Higher Education, 81(1), 82115. https://doi.org/10.1080/00221546.2010.11778971

Jordan, T. C., Burnett, S. H., Carson, S., Caruso, S. M., Clase, K., DeJong, R. J., ... Hatfull, G. F. (2014). A broadly implementable research course in Phage Discovery and Genomics for first-year undergraduate students. MBio, 5(1), e01051-13. https://doi.org/10.1128/mBio.01051-13

Kinner, D., \& Lord, M. (2018). Student-perceived gains in collaborative, course-based undergraduate research experiences in the geosciences. Journal of College Science Teaching, 48(2), 48-58. https://doi.org/10.2307/26616270 
Kline, R. B. (2005). Principles and practice of structural equation modeling (2nd ed.). New York, NY: Guilford.

Kortz, K. M., \& van der Hoeven Kraft, K. J. (2016). Geoscience education research project: Student benefits and effective design of a course-based undergraduate research experience. Journal of Geoscience Education, 64, 24-36. https://doi.org/10.5408/15-11.1

Kuh, G. D. (2008). High-impact educational practices: What they are, who has access to them, and why they matter. Washington, DC: The American Association of Colleges and Universities.

Le, P. (2020). Authentic messiness: A community-based learning model in an introduction to data, and statistics course. PRIMUS, 30(2), 147-159.

https://doi.org/10.1080/10511970.2018.1525595

Lopatto, D. (2004). Survey of Undergraduate Research Experiences (SURE): First findings. Cell Biology Education, 3(4), 270-277. https://doi.org/10.1187/cbe.04-07-0045

Lopatto, D. (2010). Undergraduate research as a high-impact student experience. Peer Review, 12(2), 27-30. Retrieved from https://www.aacu.org/publicationsresearch/periodicals/undergraduate-research-high-impact-student-experience

Madan, C., \& Teitge, B. (2013). The benefits of undergraduate research: The student's perspective. The Mentor: An Academic Advising Journal, 15. https://doi.org/10.26209/mj1561274

Marwick, J. (2012). Advancing undergraduate research at community colleges. In Characteristics of excellence in undergraduate research (pp. 36-37). Washington, DC: Council on Undergraduate Research.

McNair, T. B., \& Finley, A. (2013). Assessing underserved students' engagement in high-impact practices. Washington, DC: Association of American Colleges and Universities. Retrieved from https://www.aacu.org/assessinghips/report

National Survey of Student Engagement. (n.d.). An explanation of weighting in the NSSE institutional report. Retrieved from https://nsse.indiana.edu/nsse/reportsdata/weighting.html

National Survey of Student Engagement. (n.d.). SPSS syntax for common NSSE analyses. Retrieved from https://nsse.indiana.edu/nsse/working-with-nsse-data/syntax/index.html

O’Donnell, K., Botelho, J., Brown, J., González, G. M., \& Head, W. (2015). Undergraduate research and its impact on student success for underrepresented students. New Directions for Higher Education, 169, 27-38. https://doi.org/10.1002/he.20120

RTI International. (2019). First-generation college students: Demographic characteristics and postsecondary enrollment. NAPSA. Retrieved from https://firstgen.naspa.org/files/dmfile/FactSheet-04.pdf

Seymour, E., Hunter, A. B., Laursen, S. L., \& DeAntoni, T. (2004). Establishing the benefits of research experiences for undergraduates in the sciences: First findings from a three-year study. Science Education, 88(4), 493-534. https://doi.org/10.1002/sce.10131

Shaffer, C. D., Alvarez, C., Bailey, C., Barnard, D., Bhalla, S., Chandrasekaran, C., ... Elgin, S. C. R. (2010). The genomics education partnership: Successful integration of research into laboratory classes at a diverse group of undergraduate institutions. CBE Life Sciences Education, 9(1), 55-69. https://doi.org/10.1187/09-11-0087

Stevens, J. (2002). Applied multivariate statistics for the social sciences. New York, NY: Lawrence Erlbaum Associates.

Stout, J. (2018). Understanding why many undergraduate students don't participate in research. CRN. Retrieved from https://cra.org/crn/2018/04/understanding-why-mostundergraduate-students-dont-participate-in-research/

Tabachnick, B., \& Fidell, L. (2013). Using multivariate statistics (6th ed.). New York, NY: Pearson. Taraban, R., \& Logue, E. (2012). Academic factors that affect undergraduate research experiences. Journal of Educational Psychology, 104(2), 499-514. https://doi.org/10.1037/a0026851 
Webber, K. L., Laird, T. F. N., \& BrckaLorenz, A. M. (2013). Student and faculty member engagement in undergraduate research. Research in Higher Education, 54(2), 227-249. https://doi.org/10.1007/s11162-012-9280-5

Wei, C. A., \& Woodin, T. (2011). Undergraduate research experiences in biology: Alternatives to the apprenticeship model. CBE Life Sciences Education, 10(2), 123-131. https://doi.org/10.1187/cbe.11-03-0028

Williams, N., Hussain, H., Manojkumar, P., \& Thapa, A. (2016). An evaluation of a STEM summer undergraduate research internship scheme: Student-perceived learning gains. New Directions in the Teaching of Physical Sciences, 11(1), 1-9. https://doi.org/10.29311/ndtps.v0i11.581 
Journal of the Scholarship of Teaching and Learning, Vol. 21, No. 1, April 2021, pp. 152-170.

doi: 10.14434/josotl.v21i1.30552

\title{
Undergraduate Research Embedded Across Course Levels and Types through Scaffolded Projects
}

\author{
Sara Z. Evans \\ Kennesaw State University \\ sevan120@kennesaw.edu \\ Jocelyn Evans \\ University of West Florida
}

\begin{abstract}
This article explores how to embed an undergraduate research project within a course and summarizes the student experience in courses including undergraduate research. The authors specifically focus on how to modify and alter materials to fit with different course foci and different course levels. We have been leading an interdisciplinary, multi-year research project for the past four years. During that time, we have scaffolded a research project from year to year. Each piece of the project has been embedded within a course. However, the specific course level and content focus has changed from year to year. By embedding a research project within a class, faculty members have a unique opportunity to give their students a high-impact experience and further their own research simultaneously. We have successfully mentored and supervised students in the following formats: a freshman interdisciplinary honors course, two different undergraduate criminal justice courses made up of 5-10 students that were focused around criminological theory testing, individual directed study projects with graduate students, a 30-40 person upper level criminology research methods course, and a freshman individual directed study research project. Throughout all of these modalities, we have kept a core type of course design and course requirements but modified the components and grading criteria as needed for the type and level of course. We will summarize and discuss student assessment data both on their experience in the course as well as their achievement of student learning outcomes.
\end{abstract}

Keywords: Undergraduate research, course-based undergraduate research, and faculty professional development.

\section{Introduction}

The Council on Undergraduate Research (CUR) defines undergraduate research as "an inquiry or investigation conducted by an undergraduate student that makes an original intellectual or creative contribution to the discipline" (n.d.). Undergraduate research, scholarship, and creative activity (subsequently abbreviated as UGR) is designated as a high-impact practice (HIP) based on Kuh's original (2008) list. It has continued to be one of the most utilized and studied HIP experiences. There are three major areas of positive outcomes associated with participation in UGR. These include learning gains (either course specific or broader skills such as critical thinking) (Gray \& Phillips, 2019; Lopatto, 2007; Ishiyama \& Breuning, 2003), personal characteristics such as self-efficacy and selfesteem (Helm \& Bailey, 2013), and a greater likelihood of persisting to graduation in a timely manner and acceptance into graduate/professional school (Ishiyama \& Breuning, 2003).

While the benefits of UGR are well-documented (Brownell \& Swaner, 2010), there are many challenges associated with engaging students in a high-quality UGR experience. Faculty have finite time and resources, and UGR typically requires more than the traditional classroom experience or individual research (Beer \& Thompson, 2017). Providing a high-quality, valuable student experience 
is an important and vital part of engaging in UGR. However, faculty (especially untenured faculty) cannot ignore requirements to progress their careers through the achievement of tenure and promotion. While these two things may sometimes seem at odds, this article attests to the value of embedding undergraduate research across the curriculum and aims to provide faculty tools and strategies with which they can do both at the same time without sacrificing the quality of the experience.

Undergraduate research builds scholarly identity, improves retention, supports academic progress to degree completion, and develops soft skills that employers value. Given these benefits, institutions should encourage undergraduate research across the student academic career. Faculty engage in scholarly and creative activities within and across disciplines, and their classrooms provide valuable opportunities for including students in the research enterprise. In this piece, we report on a long-term interdisciplinary collaboration at a regional comprehensive institution involving undergraduate research across courses at different levels. Quantitative and qualitative assessment data highlight student gains and offer critical moments for reflection on best practices for faculty interested in weaving undergraduate research throughout their teaching.

\section{Literature Review}

\section{Undergraduate Research as a High-Impact Practice}

Existing scholarship on UGR highlights several dimensions of inquiry. Some researchers focus on UGR as HIP and measure the degree to which the UGR experience aligns with Kuh \& O'Donnell's (2013) essential elements of a HIP. This research generally finds that when UGR experiences include most of the essential elements, they are more successful and students report better satisfaction (Kuh \& O'Donnell, 2013). For example, surveyed students participating in UGR who reported greater effort and greater time investment from the faculty member (both essential elements) report greater benefits from the experience (Salsman, Dulaney, Chinta, Zascavage, \& Joshi, 2013).

Other studies focus on measuring the degree to which students meet desired learning outcomes that theoretically should be associated with UGR as a HIP. To measure critical thinking and communication skills, some faculty use the Association of American Colleges \& Universities (AAC\&U) VALUE rubrics for these learning outcomes (Rhodes, 2009). Campus outlets for the presentation of student posters often include an undergraduate research showcase. Gray \& Phillips (2019) present results indicating that students who engaged in UGR and presented that work were able to achieve above average skill scores for all dimensions on the VALUE rubrics. Additionally, their results show excellent interrater reliability using the rubrics, suggesting these rubrics are a promising instrument for assessing UGR (Gray \& Phillips, 2019).

While there is less longitudinal research on the benefits of HIPs, some studies do exist. Participation in HIPs in college predicts higher levels of civic engagement in adulthood, even when controlling for potential selection effects. This includes research with a faculty member (Myers, C. B., Myers, S. M., \& Peters, 2019). Additionally, the total number of HIPs a student participates in is a greater predictor of civic engagement than any one type. Lopatto (2011) used the Survey of Undergraduate Research Experiences (SURE) data to assess the impact of UGR. Results indicated that the majority of students who participated in UGR sustained or increased their interest in postgraduate education and reported the highest learning gains in "understanding of the research process in your field" (Lopatto, 2011). Taken together, these findings provide important evidence that HIPs in undergraduate education can have lasting impacts.

Finally, growing evidence suggests combining two HIPs in the same experience can have even greater impacts on learning. Combining undergraduate research with a learning community, for

Journal of the Scholarship of Teaching and Learning, Vol. 21, No. 1, April 2021. josotl.indiana.edu 
example, can enhance learning amongst first-year students (Mumford, Hill, \& Kieffer, 2017). Students benefit from the intentional design of integrating HIPs together, and the collaborative learning environment serves to facilitate deeper learning of the research content. Data on alumni-reported gains and employment/post-graduate benefits suggest that participating in UGR has a powerful impact on the pursuit of graduate education, securing employment, and perceiving learning gains such as higher-order thinking (Schmitz \& Havholm, 2015).

\section{Undergraduate Research and Progression of Academic Career}

Faculty members have many competing demands for their time and energy. The allocation of time and resources depends greatly on the workload assignment that is required by the type of institution. For most faculty, this involves some allocation of time toward teaching, research, and service. At institutions where teaching is the primary responsibility, faculty often feel that teaching and research expectations are at odds with one another (Ronnenberg \& Sadowski, 2011). This becomes even more complicated and difficult with the addition of a HIP such as UGR. Providing a high-quality experience in UGR requires more time and effort than a traditional classroom environment (Beer \& Thompson, 2017). While we recognize that this may be true, we argue that faculty can also be strategic about the way they design their courses and research projects to maximize time and energy. Embedding UGR within a course can also have benefits such as the inclusion of many more students than would be possible in a directed study format, which not only can increase the overall impact of the research experience, but it can also increase data generated from an individual project.

Many colleges and universities do not have formal policies by which to recognize excellence in UGR, especially if it happens outside the normal teaching load. Even if this work is embedded within an 'in-load' course, formal policies do not typically reflect the increased time needed for UGR compared to a typical class. Furthermore, disciplinary differences impact the degree to which this type of work is valued (Schultheis, Farrell, \& Paul, 2011). Formal recognition of UGR in tenure and promotion criteria is needed and can take many forms (Rohs, 2011; Ronnenberg \& Sadowski, 2011; Schultheis et al, 2011). While pushing for formal recognition of investment in UGR as a high-impact practice, faculty can implement other strategies to increase the impact and long-term use of the research they conduct with students, some of which are outlined and discussed next.

\section{The Role of Mentoring in Undergraduate Research}

Conducting a thorough review of the literature on undergraduate research, Linn, Palmer, Baranger, Gerard, and Stone (2015) demonstrate that mentors are crucial to the success of these high-impact experiences. Mentoring meets two significant goals when successfully implemented. Mentors help students deepen their scientific understanding as well as see themselves as emerging researchers.

Mentors ideally orient undergraduates to develop and integrate (i) conceptual knowledge and background information in the topic of the research experience; (ii) science practices such as developing an argument from evidence; and (iii) insights into the culture of the lab, including the requirements of the funding and the roles of the participants. Mentors guide students to form a scientific identity by helping them imagine roles they can play in the lab, recognize gaps in their knowledge that future courses will fill, and identify ways to contribute that also strengthen their current capabilities (Linn et al., 2015:629).

Keller, Logan, Lindwall, and Beals (2017) outline a multi-dimensional support model for mentorship developed as a diversity initiative to benefit undergraduate students from traditionally

Journal of the Scholarship of Teaching and Learning, Vol. 21, No. 1, April 2021. josotl.indiana.edu 
underrepresented backgrounds who are aspiring researchers. They identify three distinct roles for mentorship, including peer mentors, career mentors, and research mentors. Though their model pertains to the health sciences, it is easily transferable to a variety of disciplines. It only requires student peers, faculty, and research assistants in the form of lab supervisors, undergraduate student mentors, or graduate students. Keller et al. (2017) argue that the participants in this model support students holistically across the "academic, psycho-social, and research domains by virtue of their roles as faculty, peers, and researchers."

The perspectives of mentors and mentees concerning the benefits and challenges of mentoring provides valuable insight. Gunn, Lee, and Steed (2017) find that "Mentors reported the process of role modeling to be most beneficial yet challenging. Mentees reported psychological and emotional support to be most beneficial, but academic and knowledge support to be challenging". In an article that summarizes the student perspective on mentoring, Pita, Ramirez, Jaocin, Prentice, and Clark (2013) outline five essential elements that students identify are needed in a mentoring relationship, which include making yourself available, fostering community, being attentive, encouraging participation in a broader research community, and being understanding. All of these elements generally align with research conducted by scholars in this area and again come back to one of the central elements of HIPs, which is to increase high-quality student engagement.

This conforms to existing scholarship on mentoring as a first-year initiative. Institutions often structure peer-mentoring programs to support the freshman cohort because these programs are linked to student engagement and increased retention. Yomtov, Plunkett, Efrat, and Marin (2015) find that students with peer mentors "felt significantly more integrated and connected to their university at the end of their first semester compared with non-mentored students." Their results suggest that these programs help with student integration and support, which in turn reinforces retention and persistence (Yomtov et al., 2015). Honors programs often combine common curriculum in the first year with peer mentoring and living-learning opportunities to build community, improve college readiness, and grow retention.

In sum, existing scholarship on undergraduate research suggests its utility as a high-impact practice, particularly when it includes all of the essential elements of a HIP. As a HIP, undergraduate research yields significant gains for students. Done well, it improves retention and academic progress. It also enhances critical thinking, communication, and civic engagement. These are important institutional goals and student learning outcomes for undergraduate students across the curriculum. However, engaging students in UGR takes a great deal of time, effort, and resources, which can be in short supply to faculty with active research agendas. Formal and informal mentorship can help to some extent, assisting students in developing a scholarly identity and deepening their scientific understanding. It is our contention, however, that even without significant resources, faculty can adopt a pedagogical approach of scaffolding UGR throughout their course load to benefit students and advance their research agenda. We suggest that faculty can 'work smarter, not harder' when it comes to UGR.

\section{The Current Study}

The current study describes a multi-year, interdisciplinary research project that has involved multiple courses. We have embedded undergraduate research in courses across a variety of formats: a freshman interdisciplinary honors course; two different special topics courses in criminal justice made up of 515 undergraduate students focused on investigating crime and public space; multiple directed study projects with graduate students; and a 30-40 person upper-level criminology research methods course. While this project has had multiple iterations, the assessment data in this study focus specifically on two courses: one semester of a freshman level honors course, and one semester of a special topics

Journal of the Scholarship of Teaching and Learning, Vol. 21, No. 1, April 2021. josotl.indiana.edu 
criminal justice course (400 level with sophomores, juniors, and seniors). We recognize that the honors population is unique, typically drawing high-achieving students. Honors programs often suffer from a lack of diversity. However, honors curriculum provides opportunities for interdisciplinary and teambased learning through foundational experiences. It also challenges students across majors to engage in research absent any training or prior knowledge. Table 1 presents demographic characteristics of the student population participating in the freshman course used in this study to highlight the potential for embedded undergraduate research throughout the curriculum. It also provides the distribution of declared majors. In terms of the honors students, 16\% self-identified as nonwhite. An additional 5\% identified as Hispanic. Approximately $70 \%$ of the population self-identified as female. In terms of declared majors, only $8 \%$ of the class had a declared major in the social sciences - the orientation of the faculty leading the undergraduate research experience in the courses included in this study. Unfortunately, information on declared major is no longer available for the criminal justice students, but demographic information for this group is included in Table 1, as well. This group was split in half in terms of males and females and had a slightly more diverse racial/ethnic makeup, with about $33 \%$ identifying as nonwhite.

The institution at which these projects took place is a mid-sized, regional comprehensive university in the Southeast. At the time of the projects, student enrollment was about 10,000 undergraduate students. The experiences discussed in the present study attest to the benefits of a scaffolded approach to UGR. Faculty can maximize time and effort by intentionally designing research projects to be embedded within multiple courses and with various sizes of student groups. In this study, we focus on three separate courses within the overall project and examine direct and indirect measures of student learning outcomes, highlight relevant assessment instruments, and provide supportive evidence of scaffolded UGR as best practice.

\section{Pedagogical Approach of Scaffolded Undergraduate Research}

One strategy that can be utilized by faculty is to scaffold their research projects over time to work on smaller parts of a bigger research question with multiple groups of students. We encourage faculty to conceive of their broad research agenda as a funnel (see Figure 1). First, consider the 'big' question that defines the research agenda. Then, distill the question into multiple smaller research questions that could potentially be answered in the confines of one semester. By approaching a research question in this way, faculty members are able to complete meaningful sub-projects that can contribute to a larger body of results/data. Consider the types of data that could be collected and identify distinct modes of data collection to contribute to a robust data set. Finally, arrive at a single approach to addressing the research puzzle that is well-suited to examination by undergraduate students in the parameters of a course or set of courses. Assignments and assessments can also be used in multiple venues to maximize time and effort.

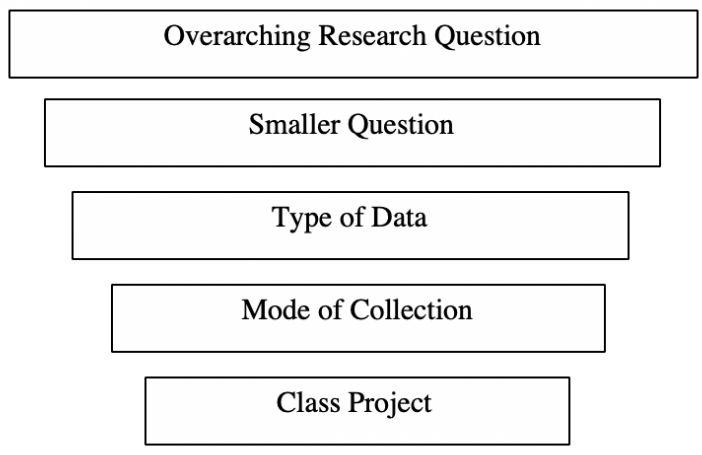

Figure 1. Conceptualizing Research Agenda for UGR.

Journal of the Scholarship of Teaching and Learning, Vol. 21, No. 1, April 2021. 


\section{Designing a Long-Term Project}

The project outlined in this article began with the question, "What is the role of public space in shaping community relationship dynamics?” We intentionally crafted a broad research question for several reasons. First, it created the ability to break off smaller research pieces that could be addressed with different groups of students. Second, it provided ample opportunity for interdisciplinary collaboration to lighten the load of student management. Figure 2 shows how this project was divided into smaller pieces. Over the course of four years, student groups of varying sizes and disciplines addressed each of these questions. For example, in the first year of the project, a large, freshman-level honors course collected observational data using standardized indices. This was most appropriate for this course level and student population. The following year, this data collection was repeated but was supplemented by a smaller group of criminal justice majors enrolled in a special topics class who collected survey data by approaching individuals face-to-face and asking them to participate in the study. We set a higher benchmark for criminal justice students in terms of both content knowledge and research methods. Additionally, we worked with individual students on directed study projects related to this overall question.

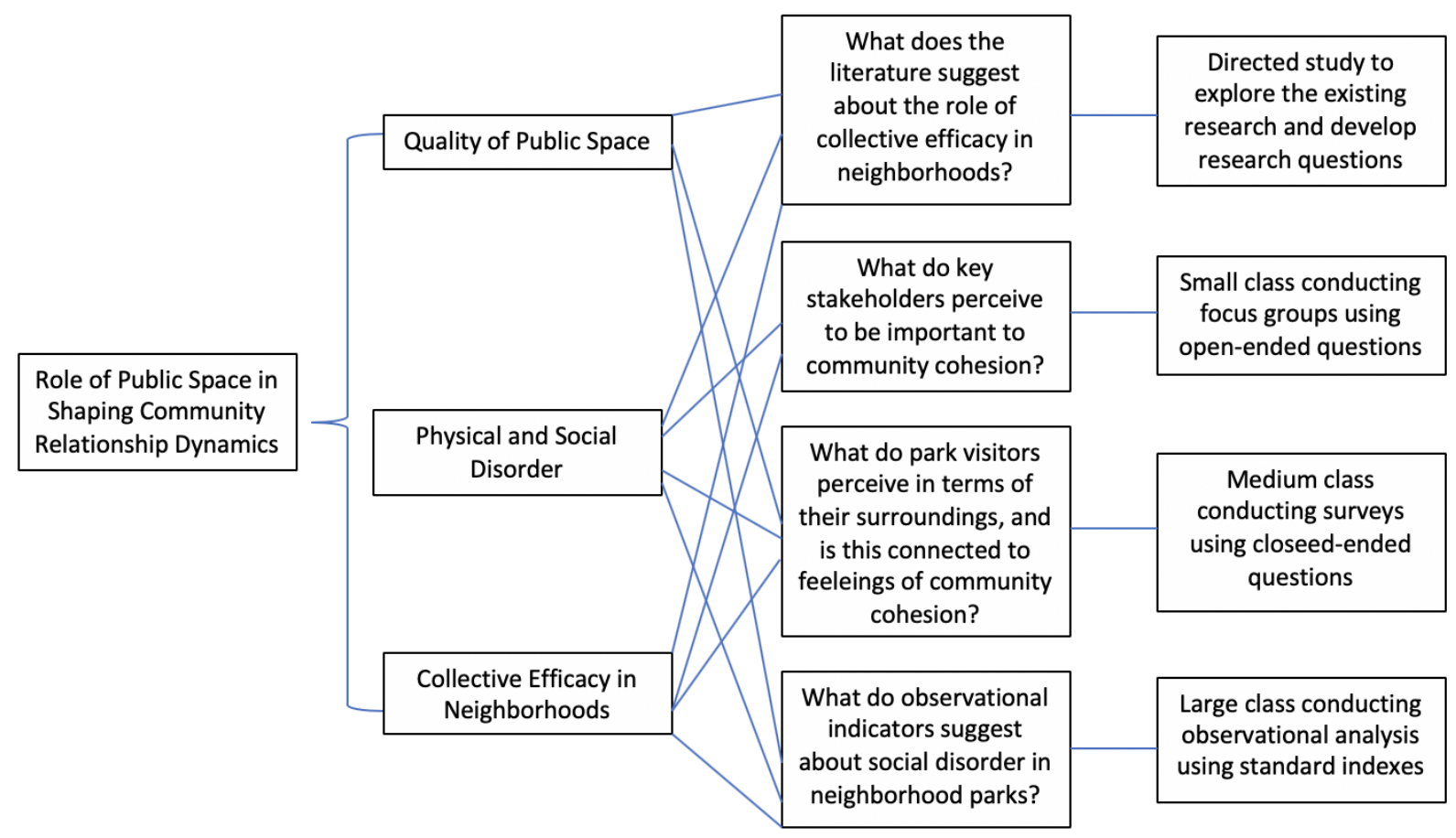

Figure 2. Interdisciplinary Research Question and Sub-Questions.

One of the most impactful aspects of this research project (especially in terms of the ability to embed a project in a course of 50+ students) is the interdisciplinary nature of the work. By bringing together multiple faculty members to work on the same project through different lenses, we generate exponentially more data with less time and effort on each individual instructor. We caution faculty members to choose their collaborators wisely, but forming a research team that is complementary in terms of disciplinary expertise and student management skills can be incredibly fruitful. Ryser, Halseth, and Thien (2009) argue that multi- and interdisciplinary teams can bring together disparate disciplinary perspectives that can fit together like a jigsaw puzzle and contribute to the whole. 